\title{
Effect of epidural anesthesia on anastomotic leakage in colonic surgery: experimental study
}

\author{
Epidural anestezinin kolon cerrahisinde anastomoz kaçağı üzerine etkisi: \\ Deneysel araştırma
}

\author{
Tayfun ADANIR, ${ }^{1}$ Murat AKSUN, ${ }^{1}$ Gülşah YILMAZ KARAÖREN, ${ }^{1}$ Türker KARABUĞA, ${ }^{2}$ \\ Okay NAZLI, ${ }^{3}$ Atilla ŞENCAN, ${ }^{1}$ Mehmet KÖSEOĞLU ${ }^{4}$
}

\section{BACKGROUND}

The association between the infusion of continuous epidural anesthesia and the anastomotic strength of colonic anastomosis was examined in an animal model.

\section{METHODS}

Fourteen white male New Zealand rabbits were included in the study and randomly assigned to two groups. Group 1 $(\mathrm{n}=7)$ had continuous epidural $0.9 \% \mathrm{NaCl}$ infusion $(0.4 \mathrm{ml}$ kg-1 bolus and $0.2 \mathrm{ml} \mathrm{kg}^{-1} \mathrm{~h}^{-1}$ infusion) and Group $2(\mathrm{n}=7)$ had continuous epidural $1 \%$ lidocaine infusion $\left(0.4 \mathrm{ml} \mathrm{kg}^{-1}\right.$ bolus and $0.2 \mathrm{ml} \mathrm{kg}^{-1} \mathrm{~h}^{-1}$ infusion). Infusions started at the beginning of the operation and were continued for six hours postoperatively. All experimental animals underwent right colon resection and colo-colonic anastomosis under general anesthesia. On the fourth postoperative day, relaparotomy was applied and the bursting pressures of the anastomosis (BPA) were measured in situ. Segments 1-cm long consisting of the complete suture lines were excised, and the levels of hydroxyproline and collagen were measured.

\section{RESULTS}

BPAs were statistically higher in the epidural lidocaine group (median: $248 \mathrm{mmHg}$; $\min 117-\max 300$ ) than in the saline group (median: $109 \mathrm{mmHg}$; $\min 47$ - max 176) $(p=0.006)$. There was no difference between the groups in terms of hydroxyproline and collagen levels in the sample tissues $(\mathrm{p}>0.05)$.

\section{CONCLUSION}

We concluded that the strength of colonic anastomosis may be increased by epidural lidocaine infusion.

Key Words: Anastomotic strength; colonic anastomosis; epidural anesthesia; lidocaine.

\section{AMAÇ}

Bir hayvan modelinde, sürekli epidural anestezi ile kolon anastomozunun gücü arasındaki ilişki araştırıldı.

\section{GEREÇ VE YÖNTEM}

Beyaz erkek 14 adet Yeni Zelanda tavşanı çalışmaya alındı ve randomize iki grup oluşturuldu. Grup 1'de (n=7) epiduralden sürekli olarak \%0,9'luk $\mathrm{NaCl}$ infüzyonu $\left(0,4 \mathrm{mlkg}^{-1}\right.$ bolus ve $0,2 \mathrm{mlkg}^{-1} \mathrm{sa}^{-1}$ infüzyon) ve Grup 2'de (n=7) epiduralden sürekli olarak \%1'lik lidokain infüzyonu $(0,4$ $\mathrm{mlkg}^{-1}$ bolus ve $0.2 \mathrm{ml} \mathrm{kg}^{-1} \mathrm{sa}^{-1}$ infuzyon) uyguland1. İnfüzyonlara, operasyonların başında başlandı ve cerrahi sonras1 6. saate kadar sürdürüldü. Bütün deney hayvanlarına genel anestezi altında sağ kolon rezeksiyonu ve kolo-kolonik anastomoz uygulandı. Cerrahi sonrası 4. gün, re-laparotomi yapılıp in situ olarak anastomoz patlama basınçları ölçüldü. Dikiş hattını içine alan $1 \mathrm{~cm}$ 'lik segment çıkartılıp, hidroksiprolin ve kollajen düzeyleri ölçüldü.

\section{BULGULAR}

Anastomoz patlama basınçları, epidural lidokain grubunda (medyan 248 mmHg - [117-300]) serum fizyolojik grubuna (medyan 109 mmHg - [47-176]) göre anlamlı derecede yüksek bulundu $(p=0,006)$. Doku örneğindeki hidroksiprolin ve kollajen düzeyleri açısından gruplar arasında fark yoktu $(\mathrm{p}>0,05)$.

\section{SONUÇ}

Kolon anastomozunun dayanıklılığının epidural lidokain infüzyonu ile artabileceğini düşünüyoruz.

Anahtar Sözcükler: Anastomoz dayanıklılığı; kolon cerrahisi; epidural anestezi; lidokain.
Presented at the Congress of Euroanaesthesia 2009 (June 6-9, 2009, Milan, Italy).

Departments of ${ }^{1}$ Anesthesiology and Reanimation, ${ }^{2}$ Surgery, ${ }^{4}$ Biochemistry, Ataturk Training and Research Hospital, Izmir; ${ }^{3}$ Department of Surgery, Mugla University Faculty of Medicine, Mugla, Turkey.
Euroanaesthesia 2009 Kongre'sinde sunulmuştur (6-9 Haziran 2009, Milan, İtalya).

Atatürk Eğitim ve Araştırma Hastanesi, ${ }^{1}$ Anesteziyoloji ve Reanimasyon Kliniği, ${ }^{2}$ Genel Cerrahi Kliniği, ${ }^{4}$ Biyokimya Bölümü, İzmir; ${ }^{3}$ Muğla Üniversitesi Tıp Fakültesi, Genel Cerrahi Anabilim Dalı, Muğla. 
Several studies comparing epidural anesthesia versus balanced general anesthesia and systemic opioid analgesia have reported a more rapid recovery of bowel function in epidural anesthesia patients..$^{[1-7]}$ However, some authors have questioned whether epidural analgesia could be detrimental to the healing of gastrointestinal anastomoses because of the increased bowel motility. ${ }^{[8]}$

There is, however, substantial experimental and clinical evidence that epidural anesthesia/analgesia is safe for patients undergoing bowel resections with anastomoses. ${ }^{[9,10]}$ In addition, studies carried out on animals and humans have demonstrated that epidural anesthesia with local anesthetics during surgical stimulation maintains intestinal mucosal blood flow and gastric mucosal $\mathrm{pH}$ at physiological levels comparable with controls treated with general anesthetics. ${ }^{[1-13]}$ It has been hypothesized that the increased mucosal flow can promote anastomotic healing. ${ }^{[14]} \mathrm{In}$ fact, retrospective cohort controlled studies suggest that regional anesthetic techniques are associated with a beneficial effect on anastomotic healing rates. ${ }^{[10-15]}$ The stimulatory effect of epidural anesthesia on gastrointestinal mobility can lead to theoretical concern about increasing anastomotic leakage, but segmental autonomic blockade may increase the blood supply to the anastomosis and improve healing. In a recently published meta-analysis, the rate of anastomotic leakage remained the same, regardless of the analgesic technique used. ${ }^{[16]}$

Epidural anesthesia is believed to benefit colorectal anastomotic blood flow because it produces sympathetic blockade. ${ }^{[17,18]}$ However, continuous infusion of epidural local anesthetic can lead to an increased incidence of anastomotic leakage owing to the stimulatory effect on bowel motility. ${ }^{[19,20]}$

In this study in a rabbit model, continuous epidural anesthesia with lidocaine was investigated in terms of the bursting pressure of colonic anastomoses (BPA). Hydroxyproline and collagen are considered as indicators of anastomotic strength, and thus their levels as measured in anastomosis sample tissues were also examined.

\section{MATERIALS AND METHODS}

\section{Animal Preparation}

The study design was approved by the Animal Investigations Ethics Committee of Ataturk Training and Research Hospital, which conforms to standard animal treatment guidelines (Home office license number: 489, Date: 11.27.2008). Fourteen white male New Zealand rabbits weighing 2150-2850 g were used in this study. Before the experiment, the rabbits were acclimated for a minimum of 72 hours (h), and carefully checked for pre-existing disease. The daily food ration was not withdrawn until the procedure was carried out. All the procedures were performed between 12:00 and 24:00 h. On the day of the experiment, anesthesia was induced with $20 \mathrm{mg} \mathrm{kg}^{-1}$ intramuscular ketamine (Ketasol 10\%, Richter Pharma AG, Wels, Austria) and $8 \mathrm{mg} \mathrm{kg}^{-1}$ intramuscular xylazine (Alfazyne $2 \%$, Alfasan International BV, Woerden, Netherlands). After cannulation into the right-ear marginal veins of the animals, anesthesia was maintained intravenously with $10 \mathrm{mg} \mathrm{kg}^{-1} \mathrm{~h}^{-1}$ ketamine and $0.9 \% \mathrm{NaCl}(5 \mathrm{mg}$ $\left.\mathrm{kg}^{-1}\right)$. The left-ear marginal artery was cannulated to measure mean arterial pressure and heart rate (Petas KMA 800, Professional Electronic Industry and Tic. AS, Turkey). The rabbits were warmed to maintain a constant body temperature. Their tracheas were not intubated, and the animals breathed spontaneously. All animals received antibiotic coverage (cephamezine 20 $\mathrm{mg} \mathrm{kg}^{-1}$, i.v.).

\section{Epidural Procedure}

The hair on the tails and waist regions of the animals were shaved after they were placed in the prone position. The tail regions were scrubbed with $10 \%$ povidone iodine. A skin incision was performed $1 \mathrm{~cm}$ from the anus, following sterile coverage, and the subcutaneous injection of $1 \%$ lidocaine. The connective tissue and paraspinal muscles were dissected and the sacral hiatus opened. An 18-G epidural catheter (Minipack SIMS Portex Ltd, Hyde, Kent, UK) was inserted into the epidural space through the sacral canal up to $4-5 \mathrm{~cm}$ cranially. Aspiration was used to check whether the dura mater was punctured. The free edge of the catheter was placed in a subcutaneous tunnel using a Tuohy needle; it was shortened and connected to a screw connector for subsequent use. The catheter was fixed to the skin and the incision sutured. Neurological injury associated with the use of the epidural catheter was evaluated after recovery from the ketamine. Paraplegia and absent flexion reflex of both lower extremities following painful stimuli on the toes of the animals were considered as positive signs of neurological injury. Any animals exhibiting signs of a neurological or motor deficit were eliminated from the study. In order to verify that the catheter was within the epidural space, $1 \%$ lidocaine $\left(0.4 \mathrm{ml} \mathrm{kg}^{-1}\right)$ was administered $5 \mathrm{~h}$ later via the epidural catheter and flushed with $0.2 \mathrm{ml}$ of $0.9 \% \mathrm{NaCl}$. If any motor or sensory blockade was observed within 5 minutes ( $\mathrm{min}$ ), it was concluded that the catheter was in the subdural and not epidural space. It was verified that motor blockade was observed after $20 \mathrm{~min}$ of drug administration. Motor function was assessed according to the criteria of Drummond and $\operatorname{Moore}^{[21]}(0$ : free motion without limitation in lower extremities; 1 : asymmetry and limitation in providing body support and walking in lower extremities; 2 : inability to provide body support by lower extremities; and 3: paralysis of both lower extremities). 
Animals were randomly assigned to two groups of seven animals chosen by computer-generated random numbers. After the evaluation of sensory blockade, animals in Group 1 were subjected to continuous epidural saline infusion $\left(0.9 \% \mathrm{NaCl}\right.$ bolus and $0.2 \mathrm{ml} \mathrm{kg}^{-1} \mathrm{~h}^{-1}$ infusions) and those in Group 2 to 1\% lidocaine (Aritmal Biosel amp, Beykoz, Turkey). The epidural catheter was used to administer $0.4 \mathrm{ml} \mathrm{kg}^{-1}$ bolus and $0.2 \mathrm{ml}$ $\mathrm{kg}^{-1} \mathrm{~h}^{-1}$ infusion to the animals in Group 2. All epidural infusions (saline or lidocaine) were continued for $6 \mathrm{~h}$ during the postoperative period, and the degree of motor blockade of animals in Group 2 was maintained at 1 or 2 (by administering additional epidural 1\% lidocaine, $0.2 \mathrm{ml} \mathrm{kg}^{-1}$, as needed). In Group 1, ketamine was infused (2-5 $\mathrm{mg} \mathrm{kg}^{-1} \mathrm{~h}^{-1}$ ) throughout the postoperative 6-h period to provide adequate analgesia.

\section{Surgery}

All animals were placed in a supine position. After the evaluation of sensory blockade, anesthesia was maintained intravenously with $10 \mathrm{mg} \mathrm{kg}^{-1} \mathrm{~h}^{-1}$ ketamine. The animals were prepared and draped, and peritoneal access was gained using midline laparotomy. An equal length of incision was used in all animals. The right colon was identified, incised and divided $5 \mathrm{~cm}$ distal to the ileocecal valve. Colonic integrity was established with end-to-end anastomoses in all animals. Atraumatic 5/0 Vicryl Rapide ${ }^{\circledR}$ stitch was used for colon anastomoses. The procedures were performed by surgeons blinded to the study groups using a standardized technique. The right colon was selected for the strength of the anastomosis model to ensure that the distance of the anastomoses was standard for all animals.

On the fourth postoperative day, relaparotomy was performed under general anesthesia by another surgeon, also blinded to group assignments. Gross observation of circumferential healing of anastomotic lines was documented. The BPA were measured in situ by another anesthetist blinded to the study groups. The anastomotic segment was dissected from the adhering tissue, opened at the mesenteric side, and a $1-\mathrm{cm}$ long segment containing the complete suture line was excised and washed gently with saline solution. The levels of hydroxyproline and collagen were measured in this sample tissue.

\section{Bursting Pressure Measurements}

Measurements were carried out in vivo, while the intestinal flow was intact. The colon was ligated $3 \mathrm{~cm}$ distal to the anastomotic line. A $14 \mathrm{G}$ silicon doublelumen catheter was inserted from the proximal end of the colon, and this end was ligated $3 \mathrm{~cm}$ above the anastomoses over the catheter with silk stitch. Saline solution was infused via one lumen of the catheter at a rate of $10 \mathrm{ml} \mathrm{min}^{-1}$. The hub of the second lumen of the catheter was attached to the transducer (Sasan pressure set, Sasan, Ankara, Turkey) for BPA mea- surement. When normal saline solution was infused via the one lumen of the catheter, the maximum pressure recorded on the monitor just before sudden loss of pressure was recorded as the BPA.

After the procedures, the animals were euthanized using thiopental (120 $\mathrm{mg} \mathrm{kg}^{-1}$, i.v.).

\section{Biochemistry Analyses}

Tissue samples were homogenized and stored at $-40^{\circ} \mathrm{C}$. An autoclave was used to hydrolyze the specimens. Chloramine-T was added to provide oxidation at room temperature. Finally, Ehrlich reactive was also used to stain samples measured at $550 \mathrm{~nm}$ using a spectrophotometer. ${ }^{[22]}$ Hydroxyproline levels were measured using standard graphics (0.05-1.5 mmol L-1) and collagen concentrations were measured $\left(\operatorname{micg} \mathrm{mg}^{-1}\right)$. These assessments were provided by a biochemist blinded to the study.

\section{Statistical Analysis}

Statistical analyses were carried out using SPSS for Windows version 15.0 (SPSS Inc., Chicago, IL, USA). Because this was a pilot study, we considered that seven animals constituted an adequate sample size for each condition investigated. Seven animals were adequate for the non-parametric ANOVA tests (Mann-Whitney U tests). In addition, the previously published data ${ }^{[10]}$ revealed that seven animals were required in each group. Results were expressed as median value (min and max value) with $95 \%$ confidence interval. The groups were subsequently compared using the Mann-Whitney $U$ test, and values of $p<0.05$ were considered as significant.

\section{RESULTS}

The weights of the animals were comparable in each group (Group 1 [n: 7]: median: $2450 \mathrm{~g}$ [min 2150 - $\max 2850$ ] vs. Group 2 [n: 7]: median: $2470 \mathrm{~g}$ [min 2190 - $\max 2840] ; p=0.2$ ). No anastomotic complications (dehiscence of the anastomosis or death) occurred in the animals, and gross observation of circumferential healing of anastomotic lines was documented.

The mean hydroxyproline levels were measured as $1.17 \pm 0.85 \mathrm{mmol} \mathrm{L}^{-1}(\min 0.18-\max 2.11)$ in Group 1 and $1.22 \pm 0.44 \mathrm{mmol} \mathrm{L}^{-1}(\min 0.8-\max 2.12)$ in Group 2 (Fig. 1). The mean collagen levels were measured as $122 \pm 89 \mu \mathrm{gm} \mathrm{L}^{-1}(\min 19-\max 221)$ in Group 1 and $128 \pm 46 \mu \mathrm{gm} \mathrm{L}^{-1}$ (min $84-\max 223$ ) in Group 2 (Fig. 2). No statistically significant difference was detected in tissue hydroxyproline and collagen levels between the groups $(\mathrm{p}>0.05)$.

Bursting pressures of the anastomoses (BPAs) were statistically higher in the epidural lidocaine group than the control group (median: $248 \mathrm{~mm} \mathrm{Hg}$ [min 117, max 300] in Group 2 vs. median: $109 \mathrm{~mm} \mathrm{Hg}$ [min 47, max 176] in Group 1; $\mathrm{p}=0.006$ ) (Fig. 3). 


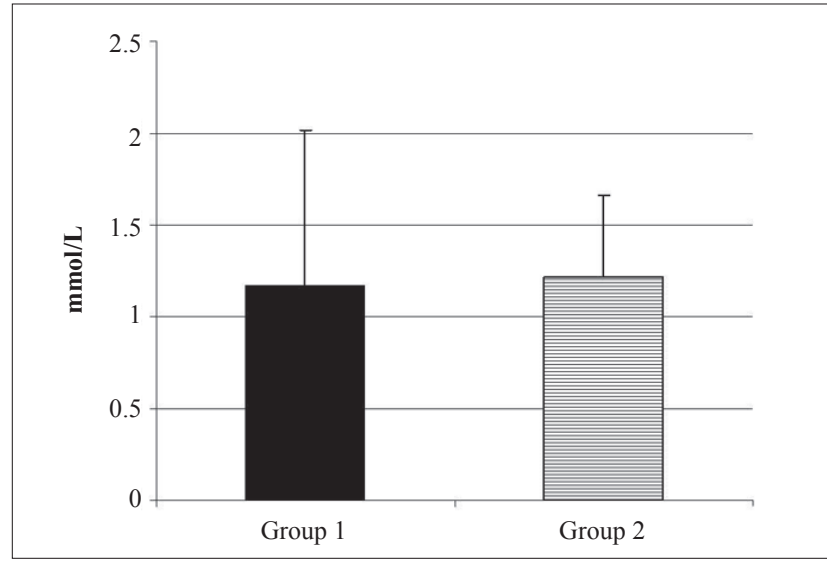

Fig. 1. Measured anastomotic tissue hydroxyproline levels were comparable between the groups $\left(\mathrm{mmol} \mathrm{L}^{-1}\right)$.

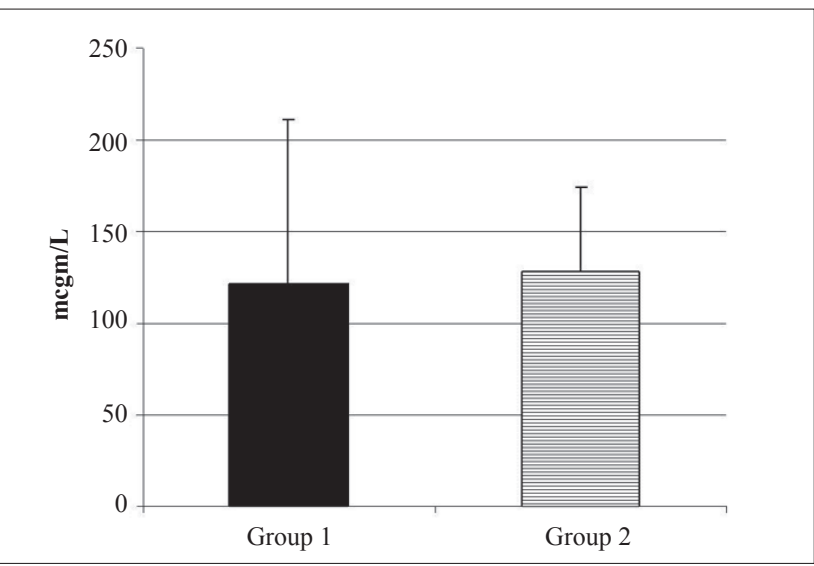

Fig. 2. Measured anastomotic tissue collagen levels were comparable between the groups $\left(\mu \mathrm{g} \mathrm{L}^{-1}\right)$.

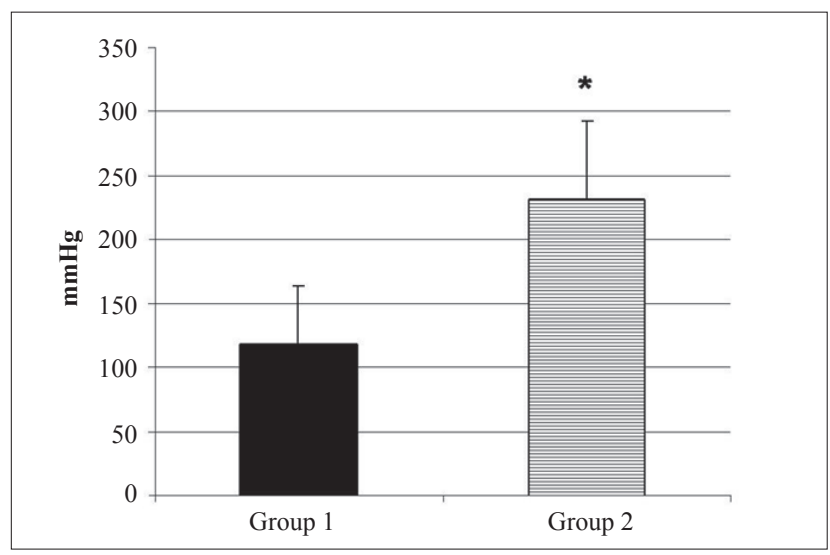

Fig. 3. Bursting pressures of the anastomoses in the epidural group were statistically higher than in controls (mmHg). ${ }^{*} \mathrm{p}<0.05$

\section{DISCUSSION}

In the present study, the tissue levels of collagen and hydroxyproline were comparable between the two groups. However, the elongation of epidural anesthesia with lidocaine for six hours into the postoperative period increased the anastomotic bursting pressure.
Anastomotic disruption is a serious complication of colorectal surgery. Adequate blood flow and oxygen perfusion are key elements in the successful healing of an anastomosis. ${ }^{[23]}$ Sympathetic blockade by epidural analgesia can increase colonic blood flow and minimize distension of the colon by stimulating propulsive forces. ${ }^{[17,18]}$ Through these mechanisms, epidural analgesia could facilitate anastomotic healing. However, case reports have suggested that early recovery of colonic motility induced by epidural analgesia could increase the anastomotic disruption rate. ${ }^{[19,20]}$ One study has further suggested that exposure to epidural bupivacaine decreases oxygen perfusion in colorectal anastomosis..$^{[14]}$

Animal, retrospective and randomized clinical studies have added to the debate regarding the effect of epidural analgesia on anastomotic integrity. Blass et al. ${ }^{[24]}$ demonstrated more advanced colonic anastomotic healing at postoperative day 7 in a canine experimental model that received epidural compared with animals receiving no epidural. However, this difference did not persist 14 days postoperatively. Another study demonstrated that rats treated with epidural ropivacaine after colon resection had better propulsive bowel function, more collagen in the anastomosis, and similar bursting pressure to controls. ${ }^{[17]}$ In a porcine model, Schnitzler et al. ${ }^{[10]}$ reported no differences between epidural bupivacaine, morphine or saline with respect to bursting pressure or hydroxyproline content of the anastomosis. No anastomotic complications occurred in these animals. Furthermore, Jansen et al. ${ }^{[25]}$ reported that the bursting pressures of intact colonic anastomoses in dogs were similar in control animals and those receiving epidural bupivacaine. However, of the four animals in the epidural group, one had a bowel intussusception and another had an anastomotic leak. The authors proposed that the faster return of colonic motility was not functionally propulsive and could be responsible for these complications. In another animal study, epidural anesthesia increased gut mucosal blood flow but reduced intermittent flow in the villus microcirculation in the presence of a decreased perfusion pressure. ${ }^{[18]}$ In a recently published meta-analysis, the anastomotic leak rate remained constant irrespective of the analgesic technique used. ${ }^{[16]}$ Although total splanchnic flow can be increased with epidural analgesia, tonometric bowel $\mathrm{pH}$ measurements demonstrate that this is accompanied by a redistribution of blood flow away from anastomoses. The inability of juxtaanastomotic vessels to dilate as much as normal bowel vessels may result in a "steal" of blood flow from the anastomoses to normal bowel. ${ }^{[14]}$ In an animal study, no significant difference in anastomotic bursting pressure seven days after anastomoses with epidural analgesia was evident when compared with conventional general anesthetic. ${ }^{[10]}$ In a recently published review 
article, no data demonstrated a harmful or beneficial effect of epidural analgesia on the rates of anastomotic leakage. ${ }^{[26]}$

Thinner nerve fibers are affected by lower local anesthetic concentrations than thicker fibers, suggesting that neuronal block is a function of diameter. With increasing local anesthetic concentration, the B fibers (preganglionic sympathetic fibers) are blocked first, followed by $\mathrm{C}$ fibers (pain and autonomic fibers) and then the largest A fibers (touch, pressure sensation and motor fibers). The aim of epidural analgesia is to produce a differential nerve block, predominantly affecting nociceptive and sympathetic fibers with no motor effects. However, critical concentrations required to block sympathetic fibers can vary considerably between patients. Therefore, applying epidural analgesia alone may not increase blood flow in the anastomotic line as it does not consistently produce sufficient sympathetic blockade.

In all previous studies concerning this issue, either intra-operative epidural anesthesia (which causes sympathetic blockade) or postoperative analgesia was applied generally. In the case of postoperative epidural analgesia, there may be no direct effect on anastomotic healing as sympathetic blockade may not occur. In the case of epidural anesthesia, sympathetic blockade occurs because of the greater concentration of local anesthetics used. For this reason, we continued epidural anesthesia (i.e., sympathetic blockade) for six hours postoperatively. Epidural anesthesia was applied to avoid the exact evaluation of sympathetic blockade in the experimental animals (by forming moderate motor blockade). The results demonstrated higher anastomotic bursting pressures in the epidural anesthesia group, an indicator of anastomotic strength and anastomotic leakage.

However, there was no difference in terms of tissue collagen and hydroxyproline levels, which are indicators of anastomotic healing. Anastomotic leakage is generally determined 5 to 7 days postoperatively. ${ }^{[27]}$ The strength of the anastomosis decreases markedly during the first 3-4 days owing to changes in the enzymatic structure of collagen bundles, but it increases after the fourth day, with prominent collagen production and accumulation. ${ }^{[28,29]}$ As anastomotic leakage is clinically determined during the 5 th to 7 th postoperative days, re-laparotomies of the experimental animals were performed on the 4th postoperative day, during which collagen production begins to increase but the strength of anastomosis is still poor. For this reason, enough time may not have elapsed for collagen development to ensue. In previous experimental studies, anastomotic bursting pressures and tissue collagen levels were generally evaluated between the 7 th to the 14th postoperative days. However, during this time, anastomotic leakage could have formed or healing could be complete. For this reason, re-laparotomies were performed during the 4th postoperative day, and anastomotic bursting pressures were measured as anastomotic leakage had not yet developed.

Shortfalls in the present study include the absence of measurements of splanchnic blood flow or oxygenation at the anastomotic line and failure to keep the sympathetic blockade for more than six hours. However, the sympathetic blockade was not maintained for more than six hours because the toxic dose level of lidocaine could have been reached. In the lidocaine group, all animals were administered over $20 \mathrm{mg}$ $\mathrm{kg}^{-1}$ lidocaine. However, further studies are required to clarify the association between longer sympathetic blockade by epidural infusion of local anesthetic and strength of colonic anastomoses.

In this experimental rabbit model, epidural $1 \%$ lidocaine, which was applied intra-operatively and continued for six hours, increased anastomotic bursting pressure (considered as an indicator of potential anastomotic strength). This could be due to the epidural lidocaine causing sympathetic blockade, resulting in increased splanchnic blood flow.

\section{Declaration of interest}

The authors have no declaration of interest.

\section{Acknowledgements}

The authors thank Dr. Ozlem Gunduz for performing the statistical analysis and the staff of the animal research laboratory for skilled technical assistance. We also thank the Foundation of Izmir Hospitals for their support of the study and BioMeds for the English editing.

\section{REFERENCES}

1. Liu S, Carpenter RL, Neal JM. Epidural anesthesia and analgesia. Their role in postoperative outcome. Anesthesiology 1995;82:1474-506. CrossRef

2. Grass JA. The role of epidural anesthesia and analgesia in postoperative outcome. Anesthesiol Clin North America 2000;18:407-28. CrossRef

3. Carpenter RL. Gastrointestinal benefits of regional anesthesia/analgesia. Reg Anesth 1996;21:13-7.

4. Ryan P, Schweitzer SA, Woods RJ. Effect of epidural and general anaesthesia compared with general anaesthesia alone in large bowel anastomoses. A prospective study. Eur J Surg 1992;158:45-9.

5. Stevens RA, Mikat-Stevens M, Flanigan R, Waters WB, Furry $P$, Sheikh T, et al. Does the choice of anesthetic technique affect the recovery of bowel function after radical prostatectomy? Urology 1998;52:213-8. CrossRef

6. Carli F, Mayo N, Klubien K, Schricker T, Trudel J, Belliveau P. Epidural analgesia enhances functional exercise capacity and health-related quality of life after colonic surgery: results of a randomized trial. Anesthesiology 2002;97:540-9. CrossRef

7. Liu SS, Carpenter RL, Mackey DC, Thirlby RC, Rupp SM, Shine TS, et al. Effects of perioperative analgesic technique 
on rate of recovery after colon surgery. Anesthesiology 1995;83:757-65. CrossRef

8. Carlstedt A, Nordgren S, Fasth S, Appelgren L, Hultén L. Epidural anaesthesia and postoperative colorectal motility--a possible hazard to a colorectal anastomosis. Int J Colorectal Dis 1989;4:144-9. CrossRef

9. Carli F, Trudel JL, Belliveau P. The effect of intraoperative thoracic epidural anesthesia and postoperative analgesia on bowel function after colorectal surgery: a prospective, randomized trial. Dis Colon Rectum 2001;44:1083-9. CrossRef

10. Schnitzler M, Kilbride MJ, Senagore A. Effect of epidural analgesia on colorectal anastomotic healing and colonic motility. Reg Anesth 1992;17:143-7.

11. Kapral S, Gollmann G, Bachmann D, Prohaska B, Likar R, Jandrasits $\mathrm{O}$, et al. The effects of thoracic epidural anesthesia on intraoperative visceral perfusion and metabolism. Anesth Analg 1999;88:402-6.

12. Sutcliffe NP, Mostafa SM, Gannon J, Harper SJ. The effect of epidural blockade on gastric intramucosal $\mathrm{pH}$ in the perioperative period. Anaesthesia 1996;51:37-40. CrossRef

13. Johansson K, Ahn H, Lindhagen J, Tryselius U. Effect of epidural anaesthesia on intestinal blood flow. Br J Surg 1988;75:73-6. CrossRef

14. Sala C, García-Granero E, Molina MJ, García JV, Lledo S. Effect of epidural anesthesia on colorectal anastomosis: a tonometric assessment. Dis Colon Rectum 1997;40:958-61. CrossRef

15. Aitkenhead AR, Wishart HY, Brown DA. High spinal nerve block for large bowel anastomosis. A retrospective study. $\mathrm{Br}$ J Anaesth 1978;50:177-83. CrossRef

16. Marret E, Remy C, Bonnet F; Postoperative Pain Forum Group. Meta-analysis of epidural analgesia versus parenteral opioid analgesia after colorectal surgery. Br J Surg 2007;94:665-73. CrossRef

17. Jansen M, Lynen Jansen P, Junge K, Anurov M, Titkova S, Ottinger A, et al. Postoperative peridural analgesia increases the strength of colonic contractions without impairing anastomotic healing in rats. Int J Colorectal Dis 2003;18:50-4. CrossRef

18. Sielenkämper AW, Eicker K, Van Aken H. Thoracic epidural anesthesia increases mucosal perfusion in ileum of rats. Anesthesiology 2000;93:844-51. CrossRef

19. Bigler D, Hjortsø NC, Kehlet H. Disruption of colonic anastomosis during continuous epidural analgesia. An early postoperative complication. Anaesthesia 1985;40:278-80. CrossRef

20. Treissman DA. Disruption of colonic anastomosis associated with epidural anesthesia. Reg Anesthesia 1980;5:22-3.

21. Drummond JC, Moore SS. The influence of dextrose administration on neurologic outcome after temporary spinal cord ischemia in the rabbit. Anesthesiology 1989;70:64-70. CrossRef

22. Reddy GK, Enwemeka CS. A simplified method for the analysis of hydroxyproline in biological tissues. Clin Biochem 1996;29:225-9. CrossRef

23. Senagore A, Milsom JW, Walshaw RK, Dunstan R, Mazier WP, Chaudry IH. Intramural $\mathrm{pH}$ : a quantitative measurement for predicting colorectal anastomotic healing. Dis Colon Rectum 1990;33:175-9. CrossRef

24. Blass CE, Kirby BM, Waldron DR, Turk MA, Crawford MP. The effect of epidural and general anesthesia on the healing of colonic anastomoses. Vet Surg 1987;16:75-9. CrossRef

25. Jansen M, Fass J, Tittel A, Mumme T, Anurov M, Titkova S, et al. Influence of postoperative epidural analgesia with bupivacaine on intestinal motility, transit time, and anastomotic healing. World J Surg 2002;26:303-6. CrossRef

26. Gendall KA, Kennedy RR, Watson AJM, Frizelle FA. The effect of epidural analgesia on postoperative outcome after colorectal surgery. Colorectal Dis 2007;9:584-600. CrossRef

27. Emet T, Bilsel Y, Tilki M, Sürmelioğlu A, User Y. Early diagnosis of colorectal anastomotic leakages by detection of bacterial genome. Ulus Travma Acil Cerrahi Derg 2005;11:195200.

28. Mast BA. Healing in other tissues. Surg Clin North Am 1997;77:529-47. CrossRef

29. Oxlund H, Christensen H, Seyer-Hansen M, Andreassen TT. Collagen deposition and mechanical strength of colon anastomoses and skin incisional wounds of rats. J Surg Res 1996;66:25-30. CrossRef 